\title{
Seminar on the Role of Financial Management and Stress Management for Families during the Covid-19 Pandemic in Sindangsari Tangerang Village
}

\author{
Dhea Zatira ${ }^{1 *}$, Amalia Indah Fitriana ${ }^{2}$, Lisdewi Mulyati ${ }^{3}$, Hendra Galuh ${ }^{4}$, Tekni Megaster ${ }^{5}$ \\ 1,2,3,4,5Fakultas Ekonomi dan Bisnis, Universitas Muhammadiyah Tangerang \\ dhea.zatira@umt.ac.id ${ }^{\left.1^{*}\right)}$
}

\begin{abstract}
Abstrak
Tujuan dari kegiatan ini adalah untuk menjelaskan dampak dan penangulangan yang terjadi akibat pandemi covid-19, menjelaskan cara mengelola keuangan keluarga, menjelaskan cara mencari sumber dana dengan memanfaatkan kreatifitas yang kita miliki, menjelaskan cara mengelola stres agar tidak berkelanjutan dimasa pandemic covid-19, menjelaskan teknik-teknik yang dapat dilakukan oleh keluarga dalam meminimalisir stress. Dilaksanakan secara online melalui Zoom Meeting. HAsil kegiatan ini Masih ada ibu rumah tangga yang belum memahami arti penting dari manajemen keuangan serta cara pembuatan anggaran keuangan yang baik khususnya dimasa pandemic seperti saat ini..

Kata kunci: Manajemen Keuangan, Manajemen Stress, Covid-19

Abstract

The purpose of this activity is toexplain the impacts and remedies that occur due to the covid-19 pandemic, explain how to manage family finances, explain how to find sources of funds by utilizing the creativity we have, explain how to manage stress so th at it is not sustainable during a pandemic. covid-19, describes techniques that families can do to minimize stress. Conducted online via Zoom Meeting. The results of this activity There are still housewives who do not understand the importance of financial management and how to make a good financial budget, especially during a pandemic like today.
\end{abstract}

Keywords : Financial Management, Stress Managemet, Covid-19

\section{Introduction}

The COVID-19 pandemic in Indonesia is part of thepandemic corona virus disease 2019 (COVID-19) on going world wide. This disease is caused by severe acute respiratory syndrome corona virus 2 (SARS-CoV-2). The first positive case of COVID- 19 in Indonesia was detected on March 2, 2020, when two people were confirmed to have contracted it from a Japanese citizen. On April 9, the pandemic had spread to 34 provinces with DKI Jakarta, West and JavaCentral Java as the provinces most exposed to the corona virus in Indonesia.

The COVID-19 pandemic has paralyzed the wheels of the Indonesian economy. Not a few companies went bankrupt because sales transactions were limited which eventually led to Termination of Employment or known as layoffs. The impact of these layoffs extends to the families of workers, not a few of the family's economic needs are disrupted because there is no source of income for the family. Families, especially housewives, 
must be able to manage finances well, starting from thinking about where and how to get sources of money that will be used to finance family needs to managing money well so that all primary family needs can be met.

When the COVID-19 pandemic disrupts many economic activities, the family is no exception. Many workers were laid off because the company they worked for could not operate, so this caused the family's needs to not be met. This is not only experienced by one or two families, but is experienced by countless families. In order to survive during the Covid-19 Pandemic, a lot of home products have sprung up, ranging from food products, clothing, art items or other necessities that were created. By utilizing the abilities and expertise possessed and even learning to make a product from various sources such as Google, finally people are able to create products that have more selling value. Supported again by the advancement of social media as a medium that can be used to market the products it makes such as Instagram, Facebook, Whatsapp or other social media, it can help sell products faster and more.

This will be a source of family income during the covid-19 pandemic, if the family income already exists, then the next step is to enter the stage of managing the money you have in accordance with the required posts. Priority must be made, meaning that the primary needs of the family must be prioritized then other complementary needs. So that the money we have can meet the needs of our family, of course, we have a lot of needs, let alone unlimited desires. If primary needs cannot be met, it will affect family life, such as hunger, stress and crime.

From the results of observations and interviews with several residents and the Sindangsari sub-district, that the problems that exist in the Sindangsari village community are the need for an explanation of the impacts and remedies that occur due to the covid19 pandemic for families, Difficulty in managing family finances, The difficulty of finding sources of funds to meet family needs, the need for stress management for housewives.

The purpose of the activity "The Role of Financial Management and Stress Management for Families during the Covid-19 Pandemic in Sindangsari Village, Tangerang", was to explain the impact and countermeasures that occurred due to the covid-19 pandemic, Explain how to manage family finances, Explain how to find sources of funds by utilizing the creativity we have, Explain how to manage stress so that it is not sustainable during the covid-19 pandemic, Explain techniques that families can do to minimize stress.

This community service is carried out to help families, especially housewives, in managing finances and dealing with stress due to the COVID-19 pandemic. The location of community service activities is carried out in Sindangsari Village, Pasar Kemis District, Tangerang Regency, Koe Pos 15560. On Friday, February 19, at 13.00 until finished.

\section{Implementation Method}

The schedule for the seminar "The Role of Financial Management and Stress Management for Families during the Covid-19 Pandemic in Sindangsari Village, Tangerang"can be seen in the table below: 
Table 1. Implementation of Seminar Activities

\begin{tabular}{|c|c|c|}
\hline Day/Date & Time & Agenda Activities \\
\hline \multirow[t]{5}{*}{$\begin{array}{l}\text { Thursday, } \\
\text { February } \\
20,2020\end{array}$} & $13.00-14.00$ & $\begin{array}{l}\text { - Seminar preparation starts from the zoommeeting } \\
\text { application and the material that will be used in } \\
\text { the presentation by the resource person. } \\
\text { - Coordination with resource persons and related } \\
\text { parties in seminars. }\end{array}$ \\
\hline & $14.00-14.30$ & $\begin{array}{l}\text { The opening, remarks by the Head of KKN, KKN } \\
\text { Advisors and Representatives of Sindangsari } \\
\text { Village as well as introductions to resource } \\
\text { persons and housewives who were the audience } \\
\text { of the seminar. }\end{array}$ \\
\hline & & $\begin{array}{l}\text { - Submission of material: introduction, family } \\
\text { financial management }\end{array}$ \\
\hline & $14.30-16.00$ & $\begin{array}{l}\text { - Submission of material: Family financial planning } \\
\text { - Submission of materials: Make a budget and } \\
\text { evaluate family finances } \\
\text { - Submission of material: Stress management for } \\
\text { families, especially housewives during the } \\
\text { COVID-19 pandemic } \\
\text { - Submission of material: Techniques to deal with } \\
\text { stress. }\end{array}$ \\
\hline & $16.00-16.30$ & - Discussion, Q\&A and closing. \\
\hline
\end{tabular}

\section{Result and Discussion}
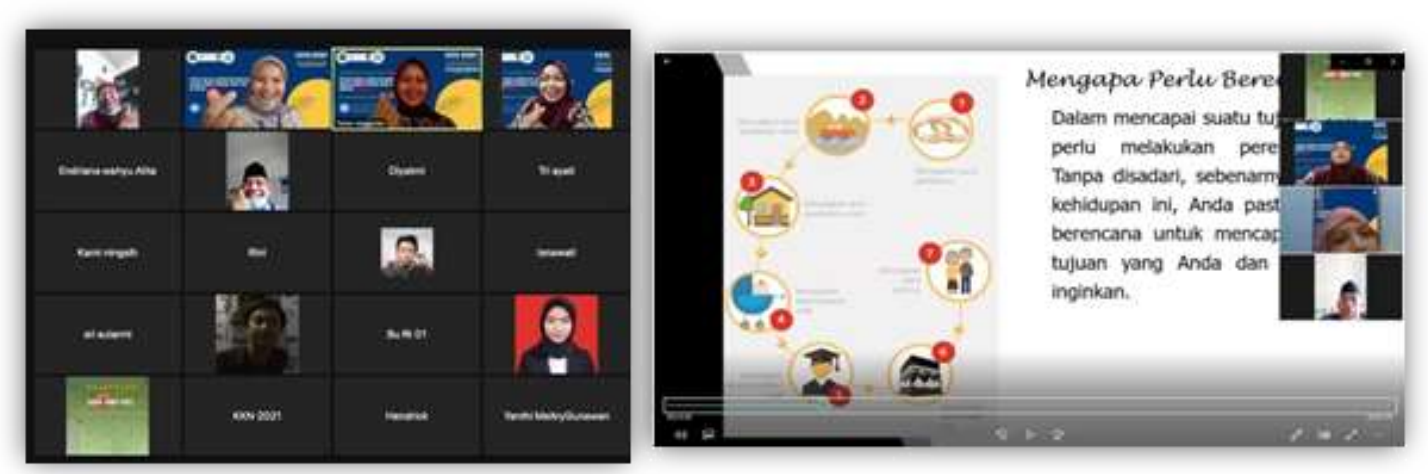

Figure 1. Zoom Meeting Activities

Materials for the Role of Financial Management and Stress Management for Families during the Covid-19 Pandemic in Sindangsari Village, Tangerang", consist of an introduction, benefits and functions of financial management; Family financial 
management planning and strategy during the COVID-19 pandemic; Make a financial budget and evaluate family finances; Explanation of Stress Management for families. especially housewives during the COVID-19 pandemic; Techniques for dealing with stress.

\section{Conclusion}

There are still housewives who do not understand the importance of financial management and how to make a good financial budget, especially during a pandemic like today. By utilizing their creativity, housewives can produce products that will become their source of income. These products can be marketed through social media such as WhatsApp, Instagram, Facebook and others. Poor financial management will affect the level of stress that housewives have, during a pandemic, in addition to sources of income that have experienced a lot of decline, housewives must also be able to teach their children who go to online schools, so special techniques are needed to overcome them. and reduce stress levels

\section{References}

Achmad, Nur, dkk. 2016. Kewirausahaan di Era Digital.Jakarta.: Direktorat Penelitian Pengabdian Masyarakat Dirjen Dikti.

Bambang, Riyanto. 2012. Dasar-dasar Pembelanjaan, Edisi 4. Yogyakarta: BPFE. Brigham Eugene F dan Houston, Joel. F. 2007. Essentials of Financial Management:

Dasar-dasar Manajemen Keuangan. Terjemahan oleh Ali Akbar Yulianto.

2011. Jakarta: Salemba Empat.

GM Suananto. 2017. The Power Of Digital Marketing. :Jakarta: Elex MediaKomputindo.

Segarahayu, R. D. (2013). Pengaruh manajemen stres terhadap penurunan tingkat stres pada narapidana di LPW Malang. UM the Learning University, 1(1).

Priyoto., 2014. Teori Sikap dan Perilaku dalam Kesehatan. Yogyakarta: Nuha Medika. Warren J. Keegen. 2009. Manajemen Pemasaran Global. Jilid Satu Edisi keenam.

Jakarta: Prenhallindo. https://id.wikipedia.org/wiki/Pandemi_COVID-19. 